\title{
REFLECTION AND COGITATION ON THE FALLACY OF POST-APARTHEID JURISPRUDENCE AND THE RESIDUE OF APARTHEID JURISPRUDENCE: THE MARIKANA MASSACRE
}

by Tshepo Twala*

\section{Introduction}

This article reflects on the fallacy of post-apartheid jurisprudence (particularly, the Marikana Massacre as a cornerstone of this 'fallacy') in South Africa. For the purposes of this article, the term 'fallacy' is used in its literal sense - that is, the so-called 'post-apartheid jurisprudence' is a mistaken belief, because there is still residue of apartheid economic policies in the 'post'-apartheid legal dispensation. This mistaken belief is demonstrated below considering the events that took place prior (i.e. economic policies), during (i.e. law from below) and after (i.e. access to Justice) the Marikana Massacre, and how one of the instrumental projects of post-apartheid legal dispensation, that of transformative constitutionalism, was hindered during these events.

This fallacy is reiterated by the post-apartheid legal dispensation's commitment to social security, as set out in section 27(1)(c) of Constitution, ${ }^{1}$ and to transformative constitutionalism, set out in the preamble of the Constitution, ${ }^{2}$ in order to narrow the socioeconomic gap that was caused by apartheid. However, government action in the economic field to combat the scope of social injustices, has yielded less than fruitful results. The economic policies that were given effect by the apartheid legal order are still prevalent in the 'post'-apartheid era. This reiterates why post-apartheid jurisprudence is a fallacy. On paper, a particular picture is portrayed while in reality, these kinds of provisions fail to make an impact. For example, during apartheid, employees were placed in hostels and paid minimal salaries, however, this practice is continuing in the democratic dispensation. ${ }^{3}$ This troubling trend manifests itself with

Second Year LLB student, University of Pretoria.

Constitution of the Republic of South Africa, 1996 (the Constitution).

Preamble of the Constitution, 1996.

Mail \& Guardian, 25 November 2016 'A minimum wage must restore the dignity of black people', https://mg.co.za/article/2016-11-25-00-a-minimum-wage-mustrestore-the-dignity-of-black-people (accessed 9 October 2017). 
the Marikana miners' placement in hostels and low salaries. It is these reasons which led to Marikana protests.

Now the question that comes into play is; but how is this a 'fallacy'? The message conveyed here is that the commitment to social security, set out in the Constitution, is only on paper. The Marikana Massacre has portrayed to us how the state failed to take reasonable measures to achieve the progressive realisation of the right to social security after it, (the state) ended up being found in the pockets of big businesses. In other words, the practice of monopoly capitalism.

For example, given the economy in South Africa, remuneration should at least be parallel with the inflation rate (or the constant rise of the consumer price index). For example, if an employee receives a R20 increment in a particular year while the increase of bread is R5 and dependents' school fees increase is R40 for that particular year, then the pay increment should be aligned with the inflation rate. Thus, should the increment be below the inflation rate, it is only fair for employees to be dissatisfied with the status quo, and commence the negotiation process with employers for better remuneration.

As will be examined below, the key question is: when the state becomes a barrier to this negotiation progress, does this action of becoming a barrier not amount to the thwarting of the right of access to social security as well as transformative constitutionalism? This can be seen through the use of the strategic lawsuit against public participation tactic through the denial of access to legal aid service by the Legal Aid Board, and the promoting of interests of big business above marginalized citizens. The same practices that the apartheid state exercised are perpetuated by our current state.

During apartheid, South Africa was characterised by discrimination, deep inequality, poverty and strife, which were rooted in, and enforced through the laws and policies of the apartheid government. ${ }^{4}$ Apartheid was entrenched in the economy, employment and political life. The fruit of this oppression was the denial of justice. Justice was a commodity accessible only to the privileged and rich, to the detriment of marginalized, the weak and the poor. It was for this reason that apartheid was declared a crime against humanity and threat to world peace by the United Nations during their 1973 General Assembly. ${ }^{5}$ The reference to Legal Aid South Africa $v$ Magidiwana and Others $^{6}$ is an attempt to cogitate the denial of access

4 For example, see Group Areas Act 41 of 1950 and the Separate Representation of Voters Act 46 of 1951.

5 Accord, 19 August 2011, 'The historic contribution of the United Nations to the resolution of conflicts in Southern Africa', http://www.accord.org.za/ajcrissues/the-historic-contribution-of-the-united-nations-to-the-resolution-ofconflicts-in-southern-africa/ (accessed 9 October 2017).

6 (2015) 6 SA 494 (CC). 
to justice in the post-apartheid era. Lack of access to courts in the democratic era provides a solid foundation for the need to re-think transformation - particularly with the state and judiciary - to facilitate the need to promote this project as provided for in the Constitution.

For the purposes of this article, the South African Police Service, (SAPS) as an organ of state, is viewed through the lens of the state's inextricable link with big businesses 'post'-apartheid. This inextricable link is manifested by the collusion between the Executive of Lonmin mines, SAPS, and a member from the executive branch of government, the current Deputy President, Dr Cyril Ramaphosa.

The 'new' South African Constitution has egalitarian commitments superimposed on a formalistic legal culture, without a strong tradition of substantive political discussion and contestation through the medium of legal discourses. ${ }^{7}$ An opening to transformation requires South African legal officers to harmonise judicial methods and legal interpretation with the Constitution's substantively progressive aspirations. ${ }^{8}$ The worth of the study of law should not be determined by its conformity with the needs of the legal fraternity, but rather its contribution to what the post-apartheid jurisprudence should entail on socio-political and legal transformation of South Africa. This article intends to critically examine perceptions of what the post-apartheid jurisprudence should entail, thereby reflecting on the intentions of the workers and the gravity of what they sought to achieve and the alleged collusion between the monopoly capital and the state. It also aims to investigate the various conceptions of social transformation as an important mechanism for the post-apartheid jurisprudence. The reflection on the ascendancy of jurisprudence in this article is further linked with the apprehension of the law as the broader reflection of what post-apartheid jurisprudence should entail. The dissection of the link between the Truth and Reconciliation Commission ${ }^{9}$ and commissions of inquiry is to reflect on how these bodies promote the culture of social injustices and whether or not they dismiss justice and accountability.

Apartheid left a legacy of great economic inequality. The commitment of the Constitution to social transformation can be read in the preamble and section 27 of the Constitution. Ideal social justice would necessitate political, economic and social transformation, reparations, the materialisation of substantive equality and a

$7 \quad$ Klare 'Legal culture and transformative constitutionalism' (1998) 14 South African Journal on Human Rights 188.

$8 \quad$ Klare (n 7 above) 188.

9 Truth and Reconciliation Commission, (TRC). 
dignified life for all, epistemic decolonisation, as well as the inculcation of active, and democratic and publicly oriented politics. ${ }^{10}$

\section{Locating the fallacy[ies]: From objective jurisprudence to a normative or 'democratic' jurisprudence}

Twenty years into 'the new South Africa', the question still (now maybe more than before) begs: What do the ideal of democracy and human rights really mean for people living in post-apartheid South Africa? To answer this question, we cannot only take these ideals at face value. ${ }^{11}$

Jurisprudence is described as the conscience of law and entails exploring law's justice and determining the 'ideal law.' ${ }^{12}$ In this article, the fallacy in post-apartheid jurisprudence should be construed as the one that has been, and is, influenced significantly by the so-called 'analytical jurisprudence', 'legal modernism', the political and moral content of the law as well as the non-progressive ideological content of law. ${ }^{13}$

In South Africa, despite an explicit constitutional commitment to democracy, transformation, substantive equality, social reconciliation, plurality, horizontality, and purposive interpretation, we still experience a legal culture overwhelmingly dominated by formalism, legalism, and liberalism. These approaches to law which have been shown to be unsuited to the development of a post-formal constitutional jurisprudence, and an active post-apartheid politics and ethics. The future of South African jurisprudence is shaped by the sequence of present-day events and how immensely we, as legal scholars, academics and citizens, contribute towards addressing our jurisprudential crisis. It is necessary to draw a brief account of Van Marle's descriptions on the state of our jurisprudence during and after the apartheid era. ${ }^{14}$ Understood very broadly and tentatively, the main approaches to law during apartheid can be identified as: (i) the scientific approach (legal formalism) adopted from a historical moment in Western Europe; and (ii) the legal positivist of Bentham and Austin. ${ }^{15}$ These approaches outline the apartheid legal dispensation, characterised by the oppressive and fallacious system

10 J Modiri 'The crises in legal education' (2014) 46(3) Acta Academia 3.

11 A Heyns 'The inoperative community of law students: rethinking the foundations of legal culture' (2014) 46(3) Acta Academia 79.

12 A Boloko 'A critical analysis on the law's ability to eradicate racism in (post) apartheid South Africa' (2016) 10 Pretoria University Law Press 47.

13 J Modiri 'Transformation, tension and transgression: reflections on the culture and ideology of South African legal education' (2013) 24 Stellenbosch Law Review 3.

14 K Van Marle 'Reflections on legacy, complicity, and legal education' (2014) 46(3) Acta Academia 200.

15 As above. 
that only recognised facts, observable phenomena, and indeterminacy of decisions taken by the apartheid judiciary.

In 1994, South African society underwent a major political and legal change that disclosed new possibilities for critique. ${ }^{16}$ These political changes signalled the constitutional project of transformation. 'Transformationists' perceive formalist legal practices as those practices which warrant being despised, destroyed and prejudiced. ${ }^{17}$ The enactment of the Constitution posed a radical challenge to this practice of formalism, legalism, purity and positivism, by establishing a new legal framework within which the law is to be understood. ${ }^{18}$ The promotion of democracy in the Constitution goes hand-in-hand with the promotion of basic human rights such as human dignity, equality and freedom. ${ }^{19}$ The acknowledgement of human rights in post-apartheid South Africa provided the potential for acknowledgement of those marginalised by apartheid. ${ }^{20}$ Thus, it is important that transformative constitutionalism facilitates social transformation in the society for the marginalised.

Ramose argues that many legal academics and legal practitioners in South Africa approach their respective scopes of the legal profession as though apartheid and colonialism has never occurred; as though new conceptions of politics, ethics and legality were not called for by the new dispensation. Furthermore, these legal academics and legal practitioners are somehow impervious to the imperatives of transformation and social justice within their legal practices and profession. ${ }^{21}$ A predicament that society experiences is the ideological difference as to what is, was, or should be the most appropriate means to bring about true social justice in our society. One ideological conflict is the establishment of the TRC. ${ }^{22}$ The TRC failed to facilitate true social justice and that it should not have functioned in our post-apartheid legal order.

The grapple against the practice of legal positivism is critical to apprehend the horizon of apartheid jurisprudence, as the current state of our 'democratic' jurisprudence reflects the legacy of apartheid jurisprudence. Ramose advances that there is an essential need for reconciliation where a conflict has emerged. ${ }^{23}$ The reconciliation acknowledges the need to restore the society, avoid inarticulate premises advanced by feminists, and equal dignity for all

16 As above.

17 As above.

18 J Fedler \& I Olckers Ideological Virgins and Other Myths (2001) 7.

19 Heyns (n 11 above) 82.

20 As above.

21 Modiri (n 13 above) 6.

22 MB Ramose 'Reconciliation and Reconciliation in South Africa' (2012) 5 Journal on African Philosophy 21-22.

23 Ramose (n 22 above) 21-22. 
citizens and families of the victims of apartheid malpractices (for example families of assassinated political activists for non-legitimate purposes) by the apartheid regime. There must be transformation through the socio-legal processes that advance reconciliation, such as the TRC, for reconciliation to take place. ${ }^{24}$ It should be noted that reconstructing our society and creating a climate of reconciliation is a long-term process and a balance between revolution and reformation. ${ }^{25}$ Sachs expostulates that the TRC should not have been facilitated within the legal framework, and by so doing the Constitution was not used properly to protect victims of past injustices. ${ }^{26}$ The Marikana Massacre is a reflection of the logical progression of apartheid policies and practices.

McKinley has argued that the rise of social movements is due to the 'push for more inclusive and more meaningful forms of direct participatory democracy that have little to do with the institutional forms of representation, within a bourgeois democratic society. ${ }^{27} \mathrm{He}$ further argues that "these movements have arisen out of the very failures of the "main currents," and the institutional framework that gives the contemporary legitimacy. 28

Apartheid left a legacy of economic inequalities and poverty. ${ }^{29}$ South African's firmly believed that the long-overdue struggle for social justice was won when the Constitution became the supreme law of the country in 1993, and reaffirmed in 1996. However, ordinary citizens did not foresee the impact of the inertia of the old apartheid order and its consequences on the wounds it caused. For example, the majority of black people are still stuck in undesirable conditions- such as living in shacks in townships, which amplify the consequential effect impact that the Group Areas Act (as already mentioned above) has had despite 'the end of the life of apartheid.' Moreover, citizens failed to foresee how the legacy of policies would impact on the national capacity to realise the dream of justice for all, and true equality. ${ }^{30}$ Due to the horrors occasioned by neoliberalism, poor communities (for the purposes of this article, the miners, ) throughout the country have banded together to challenge the effects of the state's macroeconomic policy.

24 Ramose (n 22 above) 35.

25 A Krog Country of my skull (2002) 110.

26 A Sachs The Strange Alchemy of Life and Law (2009) 76.

27 D McKinley 'Democracy, power and patronage: Debate and opposition within the African National Congress and the Tripartite Alliance since 1994' in Opposition and Democracy in South Africa, ed. R Southall (2001) 183-206, at 92.

28 T Madlingozi 'Post-apartheid social movements and the quest for the elusive 'new' South Africa' (2007) 34(1) Journal of Law and Society 80.

29 As above 78.

30 Fedler \& Olckers (n 18 above) 7.

31 Madlingozi (n 28 above) 80. 
The objective of the notion of 'transformative constitutionalism' is to achieve a true equal society, and that the commitment to transform our society lies at the heart of the new constitutional order. ${ }^{32}$ However, the tragedy of the Marikana Massacre left a lot to be desired regarding this objective and commitment. As such, it comes into consideration that the paramount aim of 'social justice' on the Marikana Massacre can never be realised if the roots of the conflict are political, economic and social are not addressed.

\subsection{A brief background of the Marikana massacre: The prisoners of hope}

The Marikana Massacre has been described as one of the most lethal uses of force to be perpetrated by South African forces, against the ordinary citizens, since the so called 'end of apartheid.' The history of South Africa has been characterized by conflict between the monopoly capitals and their ordinary exploited employees. The main objective of these exploited employees was to acquire a place at the driving-seat of the substantive distribution of wealth. The Marikana activists' unsettling presence helps call into memory those who are not immediately present, and those who are deliberately made to be absent. ${ }^{33}$ The value of [constitutional] jurisprudence should not be indexed by how well it serves the needs and expectations of the legal profession and judiciary, but by how it contributes to a new jurisprudence suited to the legal, social and political transformation of South Africa. ${ }^{34}$ The causes of this tragedy extend well beyond police training and who gave the orders and planned - or failed to plan - police action. ${ }^{35}$ These causes also extend beyond the rivalry between, primarily, the National Union of Mineworkers ${ }^{36}$ and the Association of Mineworkers and Construction Union, ${ }^{37}$ the attitude and approach of management. ${ }^{38}$ Above all, the massacre should not be seen in isolation from frequent and often violent protests around the country. ${ }^{39}$ The mineworkers' socio-economic conditions, coupled with a perceivably 'cosy' relationship between the long-established NUM leadership and the mine's management (for example, the miners felt that their concerns were not stimulated effectively as NUM wanted the workers to settle for a lesser increase than they wanted

32 P Langa 'Transformative constitutionalism' (2006) 17(3) Stellenbosch Law Review 351-353.

33 Van Marle (n 14 above) 209.

34 Modiri (n 13 above) 1.

35 Terry Bell, 27 August 2014, ‘A background to Marikana', https://terrybell writes.com/2012/08/23/a-background-to-marikana/ (accessed 2 November 2016).

36 National Union of Mineworkers (NUM).

37 Association of Mineworkers and Construction Union (AMCU).

38 Bell (n 35 above).

39 As above. 
- which is what caused the miners to title the NUM executive members as having a 'cosy' relationship with the Lonmin management) ${ }^{40}$ provided the opportunity for the emergence of newer unions; one such was AMCU which was founded by disgruntled members of the NUM. ${ }^{41}$ Amid squalor and hopelessness; anger and resentment festered and unless addressed, more tragedy is likely to follow in future. ${ }^{42}$

\subsection{The facts of the Marikana massacre}

The workers demanded a salary increase of from R5 000 to R12 000 per month from their employers. ${ }^{43}$ As anticipated, the Lonmin Marikana mine described the demands of the workers of R12 000 as impossible and denied going beyond a $10 \%$ wage increase during their negotiations with AMCU. The massacre at Lonmin constitutes 'the bloodiest tragedy' of the post-apartheid era. ${ }^{44}$ The over-reaction by a heavily armed police force which resulted in so many deaths and injuries is an obvious focus for the victims demanding accountability. ${ }^{45}$ According to Bell, questions should be asked as to why the two police helicopters did not drop teargas if there was a danger of armed conflict; why barbed wire entanglements were not set up and why live ammunition was issued and who gave the order to shoot? ${ }^{46}$

\subsection{The alchemy of apartheid: The law from below}

\subsubsection{The use of the SLAPP tactic}

A SLAPP is a lawsuit that purports to intimidate and censor critics by burdening them with the cost of a legal defence until they abandon their criticism or opposition. The SLAPP plaintiff does not intend to succeed with the lawsuit but to censor the opposition.

The purpose of the law is to attain justice. 47 This, in conjunction with the philosophy of Ubuntu, demands the restoration of the equipoise to attain justice in South African communities. ${ }^{48}$ Ramose submits that if the Constitution reflects the moral and political

\footnotetext{
40 As above.

41 As above.

42 As above.

43 As above.

44 As above.

45 As above.

46 As above.

47 MB Ramose 'I conquer therefore I am the sovereign: Reflections upon sovereignty, constitutionalism, and democracy in Zimbabwe and South Africa' in PH Coetzee \& APJ Roux (eds) The African Philosophy Reader (2003) 488.

48 As above.
} 
convictions of the people, then there is no reason why Ubuntu should not be basic to Constitutional democracy in South Africa. ${ }^{49}$ To rectify the logical progression of social injustices through Ubuntu, the restoration of the equipoise is required. In Biowatch Trust $v$ Registrar Genetic Resources and Others ${ }^{50}$ the SLAPP tactic was used to deter Biowatch from making further progress with its application. ${ }^{51}$ In casu, the High Court had ordered Biowatch to pay Monsanto's costs because Biowatch 'had compelled' Monsanto to intervene. ${ }^{52}$ This ruling was absurd because the case was between Biowatch and the State, not Monsanto. Monsanto intervened on behalf of the State to prevent Biowatch from obtaining 'sensitive' information. ${ }^{53}$ Monsanto used this tactic knowing that Biowatch was an NGO and would not have money continue with a lengthy court battle. ${ }^{54}$ The application of the SLAPP tactic in casu creates a platform to link this case to the tragedy of Marikana where the Lonmin Mines used the legal route (through collusion with the SAPS) ${ }^{55}$ not to seek social justice, but to intimidate the protesters by victimizing them. This victimization is recapitulated when it is evident that the two miners that were shot were fleeing for their lives were 300 to 800 metres away from the scene and running through the bank on the other side, but they were pursued by police officers. ${ }^{56}$ Thus, the peaceful protesting miners were unlawfully targeted - this was an execution. 57

Zikode argues that the poor are confined to dark corners and that the attack on the poor is a space of unfreedom. ${ }^{58}$ Zikode's argument on the criminalisation of activists is evident by the dispersion of demonstrators by unlawfully shooting at them whilst they posed no threat to the police officers. ${ }^{59}$ The use of the SLAPP tactic comes into place when the miners are arrested with unfounded murder charges ${ }^{60}$ - revealing that the police abused the rule of law to deter the protesting miners. ${ }^{61}$ These actions are inconsistent with section 9(1) of Constitution which states that 'everyone is equal before the law and has the right to equal protection and benefit of the law'62 and section 34 of the Constitution which guarantees that 'everyone has the right to a fair public hearing before a court. ${ }^{63}$ The rule of law

49 As above.

502009 (6) SA 232 (CC).

51 Biowatch (n 50 above) para 23.

52 Biowatch (n 50 above) para 3.

53 As above.

54 Biowatch case (n 50 above) para 2.

55 Afripost News, 24 April 2016, 'Miners Shot Down' https://www.youtube.com/ watch? $v=E N 199 W p X B m U \& t=4322$ s (accessed 02 November 2016).

56 Afripost News (n 55 above).

57 Afripost News (n 55 above).

58 S Zikode 'Poor people's movements and the law' Wits University, 2 December 2011. Accessible at http://abahlali.org/node/8551 (accessed 2 November 2016).

59 Zlkode (n 58 above)

60 Afripost News (n 55 above).

61 Afripost News (n 55 above).

62 Sec 9(1) of the Constitution, 1996. 
demonstrates that no person or institution may exercise a power or perform a function that is not conferred by law, and all public power must therefore be consistent with the Constitution, which includes power provided for in legislation. ${ }^{64}$ The behaviour of SAPS indicates that they acted above the law. Farlam J questioned General Mpempe regarding the implementation of stage-three defence. ${ }^{65} \mathrm{He}$ questioned the necessity for a stage-three defence as there was no indication of an escalation, and for this defence strategy to be implemented there must be an escalation. Referring to paragraph 23 of the SAPS head of arguments, Mpempe responded that there was no escalation. ${ }^{66}$ Mpempe's response amplifies the legacy of apartheid practices and the inextricable link between the state and big businesses in the constitutional era. During apartheid, the poor were being pushed to the dark corners by being deterred from fighting for their social rights by use of force. Unfortunately this is still happening, as portrayed by the Lonmin example.

Ironically, post-apartheid, this event reflects on the historical events that took place under apartheid; the Sharpeville Massacre in 1960 and the Soweto Uprising in 1976, where peaceful protesters were shot while fighting for social justice. ${ }^{67}$ Thus, the images of the Marikana Massacre issue a platform to develop the rethinking of transformative constitutionalism. ${ }^{68}$ Ramaphosa, who was part of the Lonmin executive and the National Executive at the time of the Marikana massacre, had previously called (during his term, in the 1990 s, as the Secretary-General of NUM) ${ }^{69}$ national leaders to remember the role that the Chamber of Mines played in pioneering some of the most oppressive features of apartheid South Africa by using fascist methods to destroy the workers' lives. ${ }^{70}$ His statement is now contradictory, as Ramaphosa is now on the other side of the table, supporting the methods that he had, before this tragedy, critiqued. ${ }^{71}$ This is contrary to constitutionalism as the sacrifice of innocent souls for financial gains reiterates the inextricable historical link between the three arms of the state and big businesses.

63 Sec 23 of the Constitution, 1996.

64 B Bekink Principles of South African Constitutional law (2012) 43.

65 The stage-three defence may only be implemented if protestors disperse into smaller groups, provided that they must be encircled and isolated and all persons properly searched for dangerous weapons and arrests to be initiated. See Farlam Comission Report 154.

66 Afripost News (n 55 above).

67 SA History, 21 March 2017, 'Sharpeville Massacre, 21 March 1961' http:// www.sahistory.org.za/topic/sharpeville-massacre-21-march-1960 (accessed 4 October 2017).

68 Afripost News (n 55 above).

69 National Union of Mineworkers 'About Us' 2017 http://num.org.za/About-Us/ History (accessed 9 October 2017).

70 Afripost News (n 55 above).

71 As above. 
The inability of the impoverished majority to influence the law 'from below' was evident when the National Police Commissioner, Riah Phiyega, argued that 'the SAPS did all in its power, to avoid a situation like this and the police members had to employ force to protect themselves from the charging group. ${ }^{72}$ The question was whether the SAPS have been honest in their account, which is clear enough that they have not. Zikode points out that 'the poor are pushed beneath the law,' which consequently amplifies the plight of the impoverished. ${ }^{73}$ Transformative constitutionalism becomes a pointless mission if the legal culture preserves social injustices and remains conservative. A conservative legal culture allows a judge to avoid substantive reasoning and evade a search for justice, and presents the law as objective when in reality it expresses particular politics and perpetuates the status quo. ${ }^{74}$ The 'protection' that Phiyega refers to is misleading- there was no 'charging group' towards the police nor a life-threatening situation imposed by the protestors. ${ }^{75}$ Through this misleading evidence, it becomes clear that the state formed a collusion with the monopoly capitalists or big businesses (in this case, Lonmin Platinum) ${ }^{76}$ Mthethwa's evidence stated that during one of his conversations with Ramaphosa, the latter said that 'he did not think that what was happening was pure industrial action in the true sense of the word, as it had criminality and violence [embedded in it]. ${ }^{77}$ This statement is troubling, because the workers peacefully regrouped at the communal land. ${ }^{78}$ Advocate Ntsebeza argues that it is monstrous to see the high 'militarisation' and huge police force where the 3000 protesting miners were neither imposing any threat and nor blocking business, national routes or strategic points. ${ }^{79}$ Dlunga, a Marikana miners' leader, reiterated that they instructed workers not to occupy the Stadium as it belonged to the Lonmin Company. ${ }^{80}$ This points towards the peaceful nature of the miners, forcing us the question why law enforcement agencies turned to the use of live ammunition to disperse protestors.

\subsubsection{Bifurcation}

The state's turn to neoliberalism has negated the Constitution's promise to 'improve the quality of life of all citizens and to free the

72 As above.

73 Zikode (n 58 above).

74 Boloko (n 12 above) 46.

75 Afripost News (n 55 above).

76 As above.

77 IG Farlam, 'Marikana Commission of Enquiry: Report on matters of public, national and international concern arising out of the tragic incidents at the Lonmin mine in Marikana, in the North West Province' 31 March 2015240.

78 Afripost News (n 55 above).

79 As above.

80 As above. 
potential of each person. ${ }^{81}$ In line with the logic of neoliberalism, most of the socio-economic rights such as the right of access to justice can only be realised 'progressively' and not immediately, and only when there are available resources to do so. ${ }^{82}$ It is important to define bifurcation as evident in the Marikana Massacre. Bifurcation connotes the inextricable division of the state and capitalists (or big businesses). ${ }^{83}$ Since the mine workers had no issue with the SAPS, it implied that in a democracy, workers are free to negotiate with their employers, and therefore the state should not be a barrier between employees' rights and employers' obligations. ${ }^{84}$ It is clear that the inextricable historical link between the state and capitalists have further obviated the ability of the impoverished majority to influence law 'from below.' Thus, this link deepens post-1994 bifurcation. The division of the branches was another derailing factor towards our post-apartheid transformation and jurisprudence. The use of the SLAPP tactic was implemented to censor the ordinary miners, as NUM had been captured and inside the pockets of the employers which was clearly evidenced by how they had opposed their members' ideologies and were ironically on the side of their members' opposition. ${ }^{85}$ It is problematic to see that post-1994 laws cause further bifurcation of the South African society as our past injustices inform us that the law cannot facilitate social reconciliation. The marginalized need to build a political and economic consciousness in order to resist poverty. ${ }^{86}$

\subsubsection{Bifurcation meets SLAPP tactic: the link between three arms of state and big businesses}

In Marikana, the SLAPP tactic was used by SAPS to deter the protestors from fighting for their social demands, and the redistribution of wealth. The redistribution of wealth is essential to eradicate the inequality gap (class difference) in order to achieve true equality. ${ }^{87}$ Bifurcation also emerged when the state (in this instance, the SAPS) was now found in the pockets of Lonmin, teaming up against the ordinary citizens, that had a clear call for 'pay cheques' that would be equivalent to the efforts. ${ }^{88}$ The Interim Constitution expressly referred to South Africa as a constitutional state. In a constitutional state the constitution reigns supreme - this means that the organs of state may only govern in terms of the prescribed structural limitations, and procedural guarantees entrenched in the 
Constitution. ${ }^{89}$ The collusion of state and the monopoly capital was reiterated on the day of the massacre; the police ordered four vans from the mortuary - a clear statement of anticipation of what was to happen thereafter. ${ }^{90}$ It was clear that the state was used to compromise the workers' demands in favour of the monopoly capital - the inextricable historical link between the arms of state and big businesses.

J Farlam states that the Commission agreed with SAPS that the latter did not have a legal duty to justify the shootings which took place at Marikana, and found that SAPS only had a duty to place evidence before the Commission which explains the circumstances under which the police acted. ${ }^{91}$ This argument by SAPS is contros bonos mores as it is in the public interest to inform the society about their justification of the shootings.

The SAPS did not see any wrongdoing nor show remorse to the setof-events. This was evident when Phiyega stated that whatever had happened showed the police officers responsible policing by ensuring safety. ${ }^{92}$ This shows the inextricable historical link between organs of state and big businesses. Interestingly, what safety was being ensured whilst there was no threat and no harm towards any public space or public's interest? If there was a need for ensuring safety, it was supposed to be minimal, not to escalate nor justify shooting. E-mail communications between the Lonmin Management, Ramaphosa, the Minister of Police, Nathi Mthethwa and Minister of Mineral Resources, Susan Shabangu highlights the inextricable link between the state and the big business because Ramaphosa lobbied the Ministers to extend the police presence to keep pressure on the miners while alerting his peers that there was a need for concomitant action towards this dastardly criminal acts. ${ }^{93}$

Advocate Mpofu argues that at the heart of this, was a 'toxic collusion' of the SAPS and Lonmin and, on a much broader level, this can be called a collusion between the state and capitalists. ${ }^{94}$ Joint operations between Lonmin and the police existed and Lonmin was completely integrated into the police strategy. ${ }^{95}$ This was evident when senior executives of Lonmin 'became part' of the police team and briefed the police officers and senior generals daily. ${ }^{96}$ Furthermore, Lonmin provided a helicopter and facilitated surveillance expeditions with the police, provided detention 
facilities, and provided the Lonmin game farm for the debriefing on the day of the massacre. ${ }^{97}$ Bifurcation had become the major derailing factor, compromising workers lives for money.

\subsubsection{Access to justice: Moving from bumper stickers to substantive interpretation and back again}

When one consults a dictionary to find the definition of Jurisprudence it is often referred to as the scientific study of law. ${ }^{98}$ However, in real South African context, it is safe to say that Jurisprudence 'is a platform of developing a capacity for discretion, a culture of justification and being substantive during adjudication, understanding how rules operate, as well as understanding the fact that when dispensing the law, the social effect of adjudication should be taken into account.' In other words, a contextual approach should be a decisive factor in the decision-making process. ${ }^{99}$

Botha submits that the Constitution contains a material or substantive foundation, which includes a justiciable bill of rights. ${ }^{100}$ The Constitution is the supreme law, and the state is bound by a system of fundamental values such as justice. ${ }^{101}$ Access to justice was hindered by an extensively due to the use of the restrictive approach (the so-called 'bumper stickers') to the interpretation of the Legal Aid Act 39 of 2014. The notion of 'bumper stickers' refers to the interpretation of legislation during the era of parliamentary sovereignty, where only the intra-textual elements were considered, instead of examining the contextual setting and purpose of the legislation. ${ }^{102}$

\subsubsection{Legal Aid South Africa $v$ Magiwana and others: A reflection of the hindring of access to justice and the inability of access to legal representation by the marginalized?}

Access to legal services from the Legal Aid Board was problematic and a central issue during the Farlam commission. ${ }^{103}$ Consequently, the examination of the restrictive approach to interpretation in Legal Aid case is very important. In casu, Mzoxolo Magidiwana, on behalf of and together with other Marikana miners, applied for state-funded

97 As above.

98 Seethe eight edition of Pocket Oxford Dictionary 511.

99 I de Villiers 20 May 2016 'Joel Modiri (JUR 110)' https://www.youtube.com/ watch?v=wacqUWfdDr0 (accessed 2 May 2016).

100 Botha (n 89 above) 186.

101 As above.

102 As above.

103 Afripost News (n 55 above). 
litigation (Legal Aid) to be represented in the commission of enquiry. ${ }^{104}$ This followed after the miners received interim private funding from the Raith Foundation for legal representation before the Commission from October 2012 to March 2013. ${ }^{105}$ After this period, the miners were unable to secure further private funding. ${ }^{106}$ The miners filed an application in the High Court, comprising two parts. Part A was brought on an urgent basis and sought interim funding for the miners' legal representation before the Commission. ${ }^{107}$ On the 30th of July 2013 the High Court dismissed Part A of the miners' application. ${ }^{108}$ This Court dismissed the application for leave to appeal for that decision. ${ }^{109}$ Part $B$, the subject of the application, challenged the failure or refusal of the President, the Minister and Legal Aid to provide the miners with state-funded legal representation. ${ }^{110}$ The High Court concluded that 'no legal framework exists within which the President and the Minister can lawfully, or are authorised to, fund the legal representation' of the miners. ${ }^{111}$ In this instance, the malpractice of legal positivism in the era of constitutionalism is signified. Thus, Klare's argument that the South African legal culture is a conservative legal culture in legal education rings true. ${ }^{112}$ It is for this reason that transformative constitutionalism becomes a pointless mission. A conservative legal culture allows a judge to avoid substantive reasoning, evade a search for justice and presents the law as objective when, in reality, it expresses particular politics and perpetuates the status quo. ${ }^{113}$

Adjudication and legal positivism hinders justice in the sense that the approach to law is formalistic, and fails to consider people's different circumstances. ${ }^{114}$ According to Klare, legal culture denotes the professional sensibilities, habits of mind and intellectual reflexes that occur in the legal setting. ${ }^{115}$ Klare's assertion does not connote that legal culture neither completely stimulates nor creates the necessary platforms to eradicate the issue of social injustice in our society. Rather, the assertion connotes that our legal culture and the platforms created thereof are not open to transforming the status quo of social injustices. ${ }^{116}$

104 Legal Aid (n 6 above) para 25.

105 Legal Aid (n 6 above) para 8.

106 As above.

107 Legal Aid (n 6 above) para 9.

108 As above.

109 As above.

110 As above.

111 Legal Aid (n 6 above) para 10.

112 Boloko (n 12 above) 46.

113 As above.

114 As above.

115 Klare (n 7 above) 166.

116 Boloko (n 12 above) 46. 
Nevertheless, the Court found that the Legal Aid's decision to refuse legal assistance was irrational and inconsistent with sections 9 and 34 of the Constitution. ${ }^{117}$ It further found that the decision to fund the families of the deceased's representation, and not the miners, irrationally and unfairly distinguished between the two groups. ${ }^{118}$ Legal Aid was therefore obliged to fund the miners' legal representation. ${ }^{119}$ The decision is instrumental as the court took into cognisance the purpose of the Legal Aid Act on a broader social scale and interpreted the Legal Aid Act extensively - which highlights the shift from 'bumper stickers' to substantive interpretation. Consistently insisting on justification, which reverberates with the spirit and purport of the Constitution, requires that the judiciary abandon the remnants of a culture of extreme deference to the executive which it has cultivated over years of adjudicating the actions of the sovereign apartheid state. ${ }^{120}$ This is in line with the preamble of the Legal Aid Act, and section 39(2) of the Constitution which demands the need to respect, protect and promote the spirit, purport and objects of the bill of rights when interpreting legislative texts. Judges must demand that branches of government present adequate justification for all their actions that impact on the constitutional rights of the citizenry.

However, in September 2014, Legal Aid appealed to the Supreme Court of Appeal. ${ }^{121}$ Before the hearing of the appeal, Legal Aid reached an agreement with the miners to provide funding for the remainder of the Commission. ${ }^{122}$ Legal Aid appealed on the basis that it laid down incorrect principles of law that would negatively impact on the work of Legal Aid, and limit the ambit of its CEO's discretion. ${ }^{123}$ The SCA dismissed the appeal because the decision would have no practical effect. ${ }^{124}$ The position of the parties would remain unaltered by the outcome of any appeal since the funding had been advanced and Legal Aid had agreed not to claim a refund in the event the appeal was in their favour. ${ }^{125}$

The SCA's interpretation of Legal Aid's argument is essential as it highlights the shift from formalism to a substantive mode of interpretation. This shift in approach is seen in Matiso $v$ Commanding

117 Legal Aid (n 6 above) para 49.

118 Legal Aid (n 6 above) para 10.

119 As above.

$120 \mathrm{M}$ Pieterse 'What do we mean when we talk about transformative constitutionalism' (2005) 20(1) South African Publiekreg/Public Law 165.

121 Supreme Court of Appeal (SCA).

122 Legal Aid (n 6 above) para 13.

123 As above.

124 As above.

125 Legal Aid (n 6 above) para 11. 
Officer, Port Elizabeth Prison, ${ }^{126}$ wherein Sachs J explained the teleological dimension of interpretation: ${ }^{127}$

[We] should not engage in purely formal or academic analysis, nor simply restrict ourselves to ad hoc techniques, but rather focus on what has been called the synergetic relation between the values underlying the guarantees of fundamental rights and the circumstances of the particular case.

When analysing the Legal Aid case, it becomes apparent that interpreting the Legal Aid Act, through a teleological framework, the true purpose of the adoption of the Legal Aid Act was to combat the societal issue of access to justice due to the unequal socio-economic structures in South Africa. Through this interpretation, the purpose of the Legal Aid Act is not to exclude people who do not meet its statutory requirements, but to help economically marginalised South Africans state-funded legal assistance.

Reiterating the need to look at the bigger picture of a legislative piece, In Minister of Safety and Security $v$ Van Duivenboend ${ }^{128}$, the Court held that the legal processes of the community must be informed by the norms and values of the South African society as provided for in the Constitution. ${ }^{129}$ Legal Aid initially distinguished between the families of the deceased miners, injured miners, and arrested miners on the basis that the participation of the former was vital for the Commission. ${ }^{130}$ This distinction is inconsistent with transformative constitutionalism as it discriminates against the surviving miners based on a specific category of a person's interests being more important than the others. ${ }^{131}$ It lacks rational basis as the weighing of certain person's interests above the others was not supposed to have been raised during the provision of state-funded legal representation. The irrationality of Legal Aid's defence was evident when they decided to fund the miners in the end.

It can be argued that Legal Aid intended to protect Lonmin's interests as they attempted all means possible (from incorrect interpretation of the Legal Aid Act to the unjustifiable distinction between the miners and the families of the deceased) to ensure that they do not aid the miners legal representation. This distinction is an example of the obstruction of transformative constitutionalism as Legal Aid justified their reason not to fund the surviving miners by drawing this distinction. Legal Aid's actions highlight that a conservative legal culture obstructs the facilitation of transformative

12619954 SA 631 (CC).

127 Matiso (n 126 above) para 46.

1282002 (6) 431 (SCA).

129 Matiso (n 126 above) para 46.

130 Legal Aid (n 6 above) para 10.

131 As above. 
constitutionalism. ${ }^{132}$ The hindering of access to justice is reiterated by Marcus as he argues that Section 34 of the Constitution did not apply to this commission specifically. ${ }^{133}$ In this matter of public importance, the practice of formalism was a central and disappointing factor present.

\subsection{Distinguishing criminal procedure from a commission of inquiry: Do commissions of enquiry truly facilitate social justice?}

This section intends to demonstrate that the commissions of inquiries have become a 'sub-division' of the TRC because of the malpractices behind their establishment as they have been used as a mechanism to avoid political liability and individual responsibility.

From the beginning and throughout its tenure, the Marikana Commission of Inquiry was mired in controversy over its dominant targeting of the miners, ${ }^{134}$ a subsequent directive from the President preventing the direct questioning of any government department and the abject failure to fully interrogate the specific role of the employer (Lonmin mines) during the commission. ${ }^{135}$ The importance of linking the commissions of inquiry to the TRC is that, like the TRC, they have become a form of 'whitewashing'. Forgiveness by verbal declaration is not enough for serving the interests of justice. ${ }^{136}$ However, if there is an acknowledgement of wrongdoing, forgiveness can be enjoyed. ${ }^{137}$ Amnesty for crimes committed within this scope of apartheid was part of the sacrifice that emerged post-apartheid, as it meant that criminal accountability compromised social justice. ${ }^{138}$ Although commissions of inquiry have the capacity to make recommendations from their findings (thus able to order prosecution as well), ${ }^{139}$ it is appropriate to describe Farlam's Commission as a mirror reflection of the TRC as both commissions reiterated the dismissal of justice over the interests of the so-called 'truth-finding.' To date, no party has been held accountable for the events before and during the massacre. ${ }^{140}$

132 Langa (n 32 above) 356.

133 Afripost news (n 55 above).

134 As above.

135 As above.

136 M Mamdani 'A diminished truth' in W James \& $L$ van der Vijver (eds) After the TRC: Reflections on truth and reconciliation in South Africa (2001) 1.

137 As above.

138 As above.

139 See Preamble of the Commissions Act 8 of 1947 as amended by General Law Amendment Act 49 of 1996.

140 News24 17 August 2017 'Not one police officer prosecuted yet for involvement in Marikana - NPA', http://www.news24.com/SouthAfrica/News/not-one-policeofficer-prosecuted-yet-for-involvement-in-marikana-npa-20170817 (accessed 4 October 2017). 
The establishment of commissions of inquiry has become an instrument that frustrates the interests of the Bill of Rights as set-out under section 34 of the Constitution, as well criminal procedure. Trends have shown that commissions of inquiry have become a tool that deter the marginalised's access to courts because after these inquiries are done, recommendations of prosecutions are often not made, if ever (e.g. The 2004 Hefer Commission set up by Thabo Mbeki). As long-suffering arms deal campaigner Terry CrawfordBrowne has noted, 'Commissions of inquiry have traditionally become places to park a hot potato until it gets cold.'141 The question is whether or not we will keep the potato hot? If not, are we facing another whitewash? Mamdani warned that to prevent the Constitution and Bill of Rights from being nothing but a hobbesian pact, a broad interpretation of rights must be followed according to which individual rights, and the rights of the minority, will have to be breached in order to redress the rights of the majority. ${ }^{142}$ Concurring with Mamdani's views on the TRC, Ramose argues that instead of promoting social cohesion, the TRC contributed to the polarised nature of post-apartheid society. ${ }^{143}$ Since the TRC aimed to promote national unity and reconciliation in a spirit of understanding which transcends the conflicts and divisions of the past, it is essential to acknowledge the past to realise the process of change and healing. ${ }^{144}$ However, the process of reconciliation should never trump the interests of justice in instances of events like the Marikana Massacre. Like its predecessors, the Farlam Commission can be remembered as an expensive and cynical exercise in burying the truth and protecting the powerful.

The TRC can be distinguished from other models of adjudication, because of its beginnings in a debate about how to manage the transition to democracy and that it is designed by a parliament, whilst a commission is established by the President. ${ }^{45}$ Like the TRC, the silence on the prosecution of accountable individuals allows for amnesty for perpetrations committed during apartheid to be part of the sacrifice that emerged in post-apartheid. This is because criminal accountability, as is the case in commissions of inquiry, dismissed justice. ${ }^{146}$

The Farlam Commission, like the TRC, did not take the form of prosecutions in criminal procedure. Resultantly, nothing fruitful has emerged from Farlam's Commission with criminal accountability, nor

141 eNCA 16 August 2017 'Parking a hot potato: Are commissions of inquiry (in)effective?' at http://www.enca.com/opinion/parking-hot-potato-are-com missions-inquiry-ineffective (accessed 4 October 2017).

142 Van Marle (n 14 above) 205.

143 Ramose (n 22 above) 35.

144 Fedler \& Olckers (n 18 above) 33.

145 D Dyzenhaus Truth, Reconciliation and the apartheid legal order (1998) 3.

146 Mamdani (n 136 above) 1. 
as an attempt to hold someone accountable. Commissions of inquiries are regarded as bodies established to investigate a history of violations of human rights in a country. ${ }^{147}$ There are four main characteristics of commissions of inquiry; its focus is on the past, not on a specific event; they aim to investigate patterns of abuse over a period of time, they are empowered and authorized by the state; and it is also a temporary body that ceases its existence by submitting a report. ${ }^{148}$ Farlam's Commission failed to investigate accountability in Marikana. In other words, the state has frustrated the purpose of commissions of inquiries. When a commission of inquiry is established, it is only established solely under the embrace of 'truth-telling' - not for the sake of at least prosecuting the responsible person(s) and promote criminal accountability.

Criminal procedure, on the other hand, is the adjudicative process of the criminal law. This adjudicative process begins with a formal criminal charge and results in the conviction of the accused. ${ }^{149}$ Criminal procedure can be either in form of adversarial or inquisitorial criminal procedure.

The significance of a commission of inquiry is that it is a unique instrument in a democratic country, like South Africa, which has been historically characterized by deep inequalities (as discussed in section 1). The appropriateness of a commission of inquiry, under circumstances such as the Marikana Massacre, is that more parties can be part of the process, and the commission can make wider structural recommendations than finding individuals guilty since it does not take the form of criminal prosecution. The commission of inquiry is unique, because it takes a form of transitional justice, involving non-judicial and judicial measures to redress legacies of rights abuses. Farlam's Commission helped with the healing process of victims, and the country, as it facilitated reconciliation of its people by uncovering the under-lying truth about human rights violations that had occurred during the Marikana Massacre. The Commission focussed on uncovering information and gathering evidence from victims and perpetrators. This was not achieved as the Farlam Commission turned a blind eye on the importance of getting the justification of Lonmin, and SAPS, and failed to criminalise the toxic collusion of Lonmin and the SAPS. Thus, the Commission only provided the state with the necessary and reliable recommendations ${ }^{150}$ on how to deal with

147 PB Hayner 'Fifteen Truth Commissions, 1974 to 1994: A comparative study' (1994) 16(4) Human Rights Quarterly 558. These violations may be committed by government, military or armed opposition forces.

148 PB Hayner Unspeakable truths (2001) 14.

149 T Humby, A Du Plessis \& L Kotze 'Introduction to law and legal skills in South Africa' (2012) 1 Oxford University Press (227-228.

150 This was extensive evidence that the commission had gathered or considered, which amounted to 39719 pages of evidence. 
protests of this nature in the future. ${ }^{151}$ Other than that, the interests of justice were derailed as it 'assisted' perpetrators in circumventing criminal accountability.

It is discernible from the above reflection on the Marikana tragedy that justice was broken prior to the Marikana killings.

\section{Conclusion}

This article reflected on the cogitation of the fallacy of postapartheid jurisprudence, particularly on the continued perpetuation of social injustices as illustrated by the events preceding the Marikana Massacre, and after the tragic event. Through my examination of the actions of the Legal Aid board denying the marginalized persons the right to legal representation, and through the strict application of the requirements for the granting of legal representation, the issue of lack of access to courts and justice continues to perpetuate social injustices. This is all despite the so-called 'shift' from an objective and formal jurisprudence to a substantive, post-apartheid jurisprudence. It is should be clear that it is important to understand transformation as a structural problem. Transformation is divided into three phases; (i) society must be inclusive by providing resources to all those who have been previously excluded, (ii) everyone must participate in processes and power structures and (ii) there must be consolidation of democracy in all economic, political and social spheres in order to effective advocate and stimulate transformation. ${ }^{152}$ Consequently, when we apply the above standards of transformation it is evident that transformation in South Africa has gone astray. South Africa's project of transformation fails to consolidate democracy in all economic, political and social spheres.

Post-apartheid jurisprudence should fabricate propositions that are conducive for socio-economic consciousness, and that will facilitate reconstruction, recovery, unity and reparation in our society. The reflection on Marikana indicates the need for social and legal realisation and real practical implementation of fundamental constitutional principles. The Legal Aid Board failing to provide legal services to the victims of the Marikana tragedy amplifies the reason why post-apartheid jurisprudence is a 'fallacy'. Through the strict application of the requirements to obtain legal representation from Legal Aid on such a tragic event points towards a formalistic approach to law is still being practiced. The state's failure to facilitate social welfare and security, despite the Constitution's commitment to transformation, indicates the failure of the state to uplift the oppressed. Consequently, the state failed in its obligation to work

151 Farlam Commission (n 77 above).

152 Boloko (n 12 above) 42. 
towards substantive equality, and access to social security, in terms of section 27 of the Constitution. The least that the state could have done before, during and after this tragic event, would be to put in place the necessary support structures for the miners to improve their lives for a better living. Dishearteningly, the victims of the Marikana tragedy are yet to receive formal apology or financial compensation from the state. 